\title{
Nationalized Banks and Long Term Lending Behaviour to Agriculture Sector in India
}

\author{
Bibhu Prasad Sahoo, Karman Kaur
}

\begin{abstract}
Finance is needed by the agricultural sector for both production and consumption. Hence, finance in agriculture is as important as other inputs being used in agricultural sector. Here the attempt has been made to to examine the lending to the agriculture sector in long run with respect to nationalized banks. Secondary data has been used from various reports and descriptive statistics have been used.
\end{abstract}

Keywords : Finance, Agriculture, Nationalized banks, Statistics.

\section{INTRODUCTION}

The economic expansion of any nation depends on various economic factors. In this globally viable world we cannot undervalue the significance of banking and the monetary mechanism. For growth of any nation, a good financial sector is imperative. But on the flipside financial inclusion has been a major issues looming on this second fastest growing economy and for the nationalized banks in India. Hence it has been a great concern for government for a quite long time.

Coordinated loaning programs are one of the vital perspectives identified with banking part across many nations. PSL is a very important policy mediation to guarantee that specific segments esteemed as vital for national improvement get reasonable credit. At the season of its commencement banks were encouraged to offer credit to need divisions to the dimension of 33.3 percent by March 1979. Today this number stands at 40 percent, out of which agribusiness loaning must be 18 percent. While the requirement for a need segment loaning program isn't the inquiry, there is a requirement for a more profound dialog on the plan, systems and components to attain its objectives. It has been seen that banks frequently show hesitance in stretching out credit to subsidize starve areas like horticulture and miniaturized scale and little endeavors, on which biggest share of the populace is reliant.

\section{LITERATURE REVIEW}

Literature review is one of the vital components of any research work Therefore, we tried to study many existing available literature to eliminates the prospect of repetition of study and increases the scope of adding new dimensions. Further, it also helps us in removing the shortcomings and limitation of our present research work.

Study have found states that the market environment of the agricultural sector in developing countries still requires

Revised Manuscript Received on September 15, 2019.

* Correspondence Author

Dr. Bibhu Prasad Sahoo, Assistant Professor, SGTB Khalsa College, University of Delhi, New Delhi,India

Karman Kaur, Assistant Professor, SGTB Khalsa College, University of Delhi, New Delhi,India special government attention [1]. Some study revealed that credit to agriculture sector is poor [2]. It was also found that banking sector is hesitant to provide loans to small and marginal farmers. Heartarska and Nadolnyak(2015) in their study found positive relation between rural sector domestic product and agriculture lending. Mishra \& Mohapatra (2017) reveals in their study, that ,the structure of the sources of credit has witnessed a clear shift. Yadav (2018) study reveals that institutional credit system in India is improving gradually. However, credit system in India for agriculture is not effective.

Shekodra (2018) showed that banks are resist giving less loans to micro financial institution with respect to all small loans to rural sector taken in aggregate.

After scanning above literature available from different published sources indicates that very few detailed studies have been conducted in India in the field of trend analysis with reference to Nationalized banks in India .In view of this our study intends to examine empirically the long-term lending behavior of Agricultural sector which is one of the important constituent of the lending to priority sector in India.

\section{OBJECTIVE AND HYPOTHESIS OF THE STUDY}

Since it is important to include marginal farmers in financial inclusion objective, with respect to agriculture lending in the country. Therefore, this study analysis the trend in long term behavior towards agriculture sector.

Along with the objective, our study also test the following hypothesis.

$H_{o}$ : "There is no significant trend in total agricultural lending of nationalized banks."

$H_{1}$ : "There is a significant trend in total agricultural lending of nationalized banks."

\section{DATA \& METHODOLOGY}

To achieve aforesaid objective, our study has considered the annual data on agricultural lending provided by Indian nationalized banks from $1^{\text {st }}$ April 2006 to $31^{\text {st }}$ March 2018 (total span of 12 years)

To study the behavior of lending to agricultural sector by nationalized bank, both descriptive statistics and regression analysis has been used in the present study.

To analyze the long term lending trend, both regression and descriptive statistics tools have been materialized over the period of years. The following model has been constructed to find out trend of agricultural sector lending by nationalized banks.

Agricu lending $=\alpha+\beta *$ Time $($ in years $)+\varepsilon$ 
Where agricultural lending is regressand , $\alpha$ is intercept, $\beta$ represents the long term trend in behavior of agricultural lending and time is considered as an independent variable.

If agriculture lending of banks have been increasing over period of time then $\beta$ is positive. However, if $\beta$ is not significant, it indicates the agricultural lending by nationalized banks has remained same over the period of time. Separate regression model have been applied to analyze the behavior of credit extended to agriculture by each bank.

\section{EMPIRICAL RESULTS AND ANALYSIS}

\section{Trend Analysis of Agricultural Lending}

Agriculture is one of the topmost priorities of India's social and economic policies since independence. Agriculture has a significant contribution in India's GDP, export and employment. But on the flipside this sector faces lot of challenges such as vagaries of monsoons, small size of land holdings, transition in the Indian economy from a purely agrarian to a manufacturing and services based economy. Thus in the given scenario lending to agriculture sector as a crucial element of PSL holds an important position.

The results indicate that average agricultural lending is found to be highest in case of Punjab National Bank (34089.18Crores) followed by Canara Bank (30458.20Crores). This impressive lending by Punjab National Bank is a result of its vast presence in unbanked areas with a motive of strengthening the rural credit delivery system. As far as Canara Bank is concerned there has been a considerable increase in bank's advances under agriculture portfolio covering over 53 lakh farmer's in 2015. However minimum average agricultural lending is by Punjab and Sind Bank (4677.04Crores), Dena Bank (5951.86Crores) and Vijaya Bank ( 6048.60Crores). Here also Dena Bank,Vijaya Bank and Punjab and Sindh Bank are lagging behind in fulfilling their social obligation with respect to agricultural lending. These banks need to adapt to various vertically integrated policies to augment the credit flow. This has been shown in the table in appendix

On the basis of average agricultural lending banks are divide into three groups. These groups are banks with average agricultural lending less than ` 10000 Crores, average agricultural lending between `10000-15000 Crores and banks with average agricultural lending more than `15000 Crores. The frequency distribution of nationalized banks is shown below.

The results indicate that 6 out of 19nationalisedbanks (31.6percent) have the average agricultural lending less than ' 10000 Crores, whereas 6 banks (31.6percent) have average agricultural lending between `10000-15000 Crores and only 7 banks (36.8percent) have average agricultural lending more than " 15000 Crores. In the study an effort has been made to study the long term behavior of agricultural lending by nationalized banks during the period 2006-2015.

The results of regression model are shown in the table attached in Appendix.

The result of bivariate regression model indicates that probability value of $t$ statistics for all banks is found to be less than 5percent level of significance hence with 95percent confidence limit null hypothesis of no long term trend in agricultural lending cannot be accepted. Thus it can be concluded that there is a significant positive trend in the behavior of total agricultural lending of all nationalized

banks. The $\mathrm{p}$ value of $\mathrm{F}$ statistics is found to be significant in case of all selected banks which represents that regression model is statistically fit and $\mathrm{R}$ square represents the magnitude of existed long term trend of nationalized banks. It is found that Canara Bank has the highest trend value of 5061.139. This indicates that on an average total agricultural lending of Canara Bank increases by `5061.139 Crores every year.

Canara Bank is followed by Punjab National Bank where it is found that on an average total agricultural lending of bank increases by ' 5033 Crores every year. The lowest trend is found in the case of Punjab and Sind Bank where agricultural lending increases total by ` 732.584 Crores every year. Even though Punjab and Sindh Bank has implemented special schemes like Special Agricultural Credit Plan to increase the flow of credit to agriculture but then also bank is last in the race. This exhibits a need to channelize priority sector credit in a socially desirable manner by bank. Pushing bank credit to agriculture sector should be seen as an important objective by all nationalized banks as lack of bank funding to this sector is a roadblock to improve the agricultural production.

On the basis of long term trend of agricultural lending banks are divided into three categories. These are banks with annual trend of less than `1500 Crores, between `1500-2500 Crores and more than $` 2500$ Crores. the frequency distribution is shown in the appendix

It is clearly visible from the table that in the case of agricultural lending 7 banks (36.8percent) have an annual trend of less than ' 1500 Crores, 5 banks (26.3percent) have an annual trend of $1500-2500$ Crores, whereas 7 banks (36.8percent) have an annual trend more than `2500 Crores. It means that agricultural lending of 7 out of 19 banks increases by less than ' 1500 Crores annually, agricultural lending of only 5out of 19 banks increases between `1500-2500 Crores and agricultural lending of 7 out of 19 banks increases by more than `2500 Crores every year.

\section{CONCLUSION}

Traditionally, agriculture is one of the high exposure areas for banks. But a look at the bank funding pattern to the agriculture sector shows that lack of bank funding despite of a significant positive trend during the study period. It has been observed by many researchers that micro and small enterprises have leveraged the increased supply of credit to grow, whereas agriculture has lagged behind.

It is in the mandate of the nationalized bank to provide loans to agriculture sector to enhance their farming practices. Farming sector need loans for buying seeds, fertilizers, machines, pesticides etc. and for this they require good credit system in the rural sector. The study found that the total credit extended to agricultural sector has been increasing, but the rate of change is not constant across banks. Further the study concluded that Canara bank had the highest trend value of 5061.13, indicating average increase in total lending to agricultural sector. The lowest trend is found for Punjab \& Sindh bank where total lending to agricultural sector increased by only meager 732.58 crores each year. According to statistics, nationalized banks are now rapidly increasing their base in rural sector. They have started to provide various doorstep utility services as well. It is surprising to note that even after around five decades of priority sector lending 
prescription; it was observed that certain important sector in the economy continue to suffer from inadequate credit flow. Hence, this study concludes that, to mobilize the credit for agriculture sector is important drivers of growth for Indian economy.

\section{REFERENCES}

1. Giechler T (1998) ,Investment and funding land scape, rural and agricultural finance, Deutsche gesells chaft for international zusammenarbeit Gmbh

2. Golait Ramesh (2007) current issues in agriculture credit in India, Occasional paper,vol28,no-1,pp79-98.
3. Hartarska valentine \& Nadolnyak Denis (2015) Agricultural credit and economic growth in rural areas, Agricultural finance review, vol75,pp-302-312.

4. Ram kumar R (2013),Bank credit to agriculture in India: Trends in the 1990 and 2000, The Marxist,XXIX3.

5. Mishra Ajit kumar \& Mohapatra Upasana (2017),Agricultural finance in India-An over view, International journal of engineering sciences and research technology, pp-411-417

6. Mohan R(2004) Agriculturre credit in India: status, issues and future agenda, Economic and political weekly, pp-1013-1021.

7. Reddy suba (2005) ,Agricultural finance and management,Oxford \& IBH publishing company private Ltd .New Delhi.

8. Shkodra Jehona(2018) Impact of agricultural finance in rural area- case study Kosov, Bulgarian journal of agricultural science. Pp-737-741.

9. Yadav sunil singh (2018) source of agricultural credit in Indian agricultural credits, Shodh Drisht ,Vol.8,No3,pp-161-166.

APPENDIX

Table 1: Descriptive Analysis of Total Agricultural Lending

\begin{tabular}{|l|l|l|l|l|l|}
\hline $\begin{array}{l}\text { S. } \\
\text { No }\end{array}$ & Name of Bank & $\begin{array}{l}\text { Mean } \\
\text { (Crores) }\end{array}$ & $\begin{array}{l}\text { Standard } \\
\text { Deviation }\end{array}$ & Minimum & Maximum \\
\hline 1 & Allahabad Bank & 13647.61 & 6219.45 & 5726 & 24679 \\
\hline 2 & Andhra Bank & 11091.34 & 6213.43 & 4064 & 20894 \\
\hline 3 & Bank of Baroda & 21935.22 & 9912.16 & 6869 & 37403 \\
\hline 4 & Bank of India & 22196.30 & 11617.38 & 9020 & 43183 \\
\hline 5 & Bank of Maharashtra & 6808.70 & 3994.54 & 2750 & 15521 \\
\hline 6 & Canara Bank & 30458.20 & 15851.81 & 12032 & 58868 \\
\hline 7 & Central Bank of India & 18955.21 & 9553.36 & 6866 & 35957 \\
\hline 8 & Corporation Bank & 6873.36 & 4563.08 & 1935 & 15664 \\
\hline 9 & Dena Bank & 5951.86 & 3228.84 & 2363 & 12312 \\
\hline 10 & Indian Bank & 10373.24 & 5209.65 & 4249 & 19164 \\
\hline 11 & Indian Overseas Bank & 15766.89 & 7804.78 & 5954 & 26990 \\
\hline 12 & $\begin{array}{l}\text { Oriental Bank } \\
\text { Commerce }\end{array}$ & 12581.18 & 6464.20 & 4480 & 22541 \\
\hline 13 & $\begin{array}{l}\text { Punjab } \\
\text { Bank and }\end{array}$ & 4677.04 & 2370.72 & 1558 & 8654 \\
\hline 14 & Punjab National Bank & 34089.18 & 15757.05 & 14587 & 60006 \\
\hline 15 & Syndicate Bank & 14797.35 & 6615.24 & 5871 & 26205 \\
\hline 16 & UCO Bank & 11184.15 & 4677.21 & 4397 & 19687 \\
\hline 17 & Union Bank of India & 18095.04 & 8467.20 & 8127 & 35175 \\
\hline 18 & United Bank of India & 5674.50 & 3010.00 & 2327 & 9599 \\
\hline 19 & Vijaya Bank & 6048.60 & 3084.90 & 2456 & 11974 \\
\hline & & & & & \\
\hline
\end{tabular}

Table 2: Distribution of Average Agricultural Lending by Nationalised Banks

\begin{tabular}{|l|l|l|}
\hline $\begin{array}{l}\text { Average } \\
\text { Agricultural } \\
\text { Innding }\end{array}$ & Frequency & Percent \\
\hline $\begin{array}{l}\text { Less than } ` 10000 \\
\text { Crores }\end{array}$ & 6 & 31.6 \\
\hline 10000-15000 Crores & 6 & 31.6 \\
\hline $\begin{array}{l}\text { More than ‘15000 } \\
\text { Crores }\end{array}$ & 7 & 36.8 \\
\hline Total & 19 & 100.0 \\
\hline
\end{tabular}

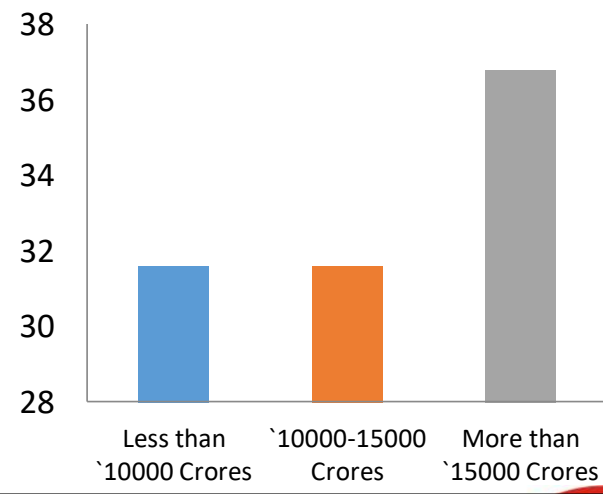


Table 3: Distribution of Annual Trend of Agricultural Lending

\begin{tabular}{|l|l|l|}
\hline $\begin{array}{l}\text { Annual Trend of } \\
\text { Agricultural } \\
\text { Indina } \\
\text { Less than `1500 } \\
\text { Crores }\end{array}$ & Frequency & Percent \\
\hline '1500-2500 Crores & 5 & 36.8 \\
\hline $\begin{array}{l}\text { More than ‘2500 } \\
\text { Crores }\end{array}$ & 7 & 26.3 \\
\hline Total & 19 & 36.8 \\
\hline
\end{tabular}

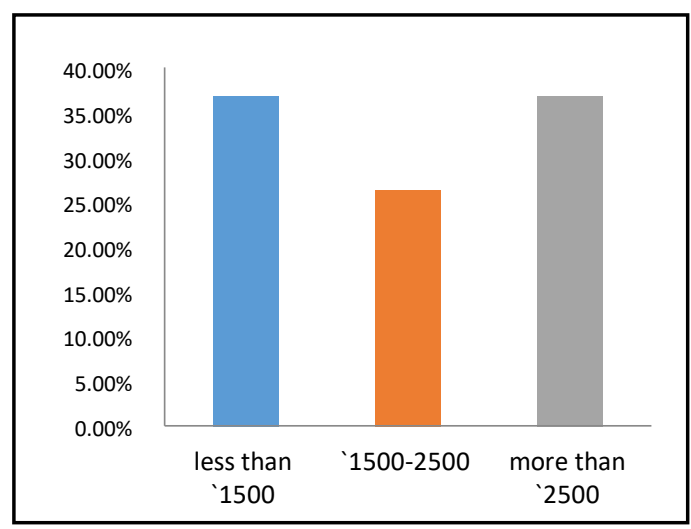

Figure 1: Average Agricultural Lending by Nationalised Banks

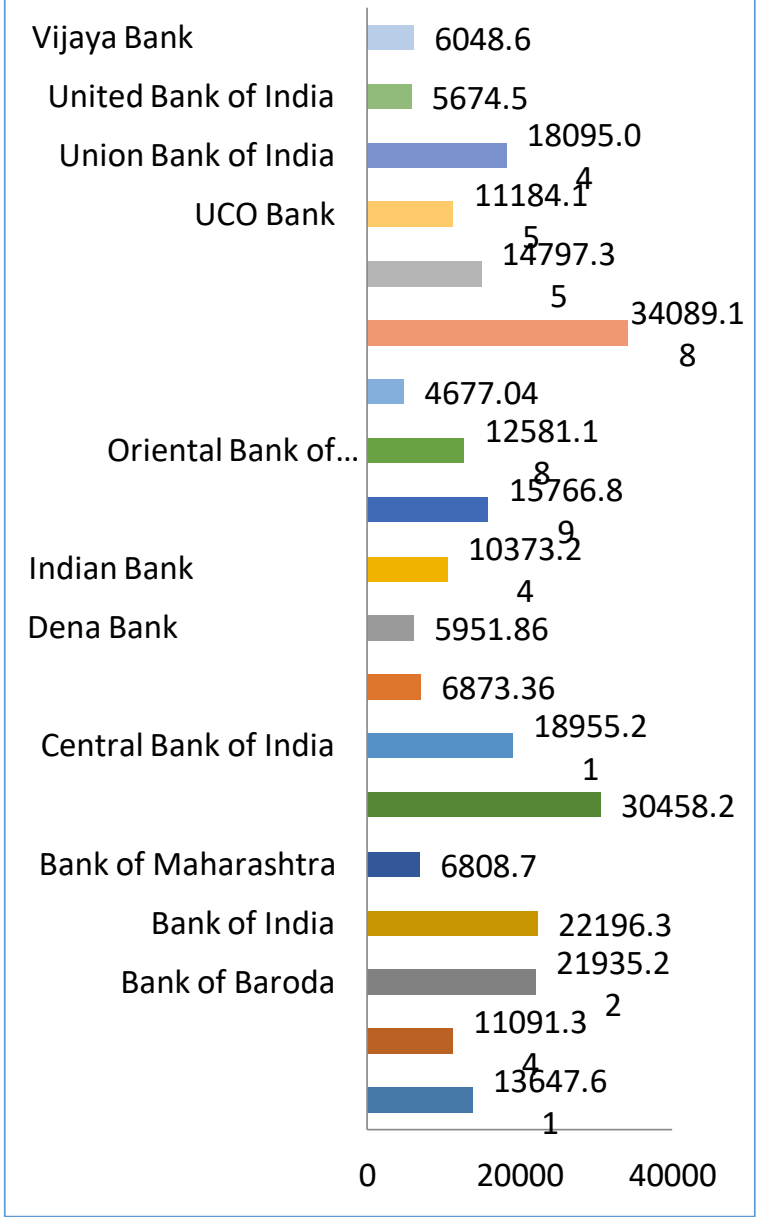

Table 4: Regression Analysis of Total Agricultural Lending

\begin{tabular}{|c|c|c|c|c|c|c|}
\hline Name of Bank & $\begin{array}{l}\text { Dependent } \\
\text { variable }\end{array}$ & $\begin{array}{l}\text { Independent } \\
\text { Variable }\end{array}$ & 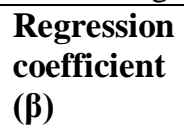 & $\begin{array}{l}\text { t-test } \\
\text { (p value) }\end{array}$ & $\begin{array}{l}\text { F-test } \\
\text { (p value) }\end{array}$ & $\begin{array}{l}\text { R } \\
\text { Square }\end{array}$ \\
\hline $\begin{array}{l}\text { Allahabad } \\
\text { Bank }\end{array}$ & $\begin{array}{l}\text { agricultural } \\
\text { lending }\end{array}$ & time (in years) & 2008.00 & $\begin{array}{l}13.10 \\
(\mathbf{0 . 0 0 0}) * *\end{array}$ & $\begin{array}{l}171.83 \\
(\mathbf{0 . 0 0 0 )} * *\end{array}$ & $95.6 \%$ \\
\hline $\begin{array}{l}\text { Andhra } \\
\text { Bank }\end{array}$ & $\begin{array}{l}\text { agricultural } \\
\text { lending }\end{array}$ & time (in years) & 1977.99 & $\begin{array}{l}10.22 \\
(\mathbf{0 . 0 0 0 )} * *\end{array}$ & $\begin{array}{l}104.61 \\
(\mathbf{0 . 0 0 0 )} * *\end{array}$ & $92.9 \%$ \\
\hline Bank of Baroda & $\begin{array}{l}\text { agricultural } \\
\text { lending }\end{array}$ & time (in years) & 3242.04 & $\begin{array}{l}20.13 \\
(\mathbf{0 . 0 0 0 )} * *\end{array}$ & $\begin{array}{l}405.39 \\
(\mathbf{0 . 0 0 0}) * *\end{array}$ & $98.1 \%$ \\
\hline Bank of India & $\begin{array}{l}\text { agricultural } \\
\text { lending }\end{array}$ & time (in years) & 3640.33 & $\begin{array}{l}8.48 \\
(\mathbf{0 . 0 0 0 )} * *\end{array}$ & $\begin{array}{l}72.05 \\
(\mathbf{0 . 0 0 0 )} * *\end{array}$ & $90 \%$ \\
\hline $\begin{array}{ll}\text { Bank } & \text { of } \\
\text { Maharashtra }\end{array}$ & $\begin{array}{l}\text { agricultural } \\
\text { lending }\end{array}$ & time (in years) & 1129.97 & $\begin{array}{l}4.69 \\
(\mathbf{0 . 0 0 2}) * *\end{array}$ & $\begin{array}{l}22.02 \\
(\mathbf{0 . 0 0 2}) * *\end{array}$ & \\
\hline
\end{tabular}


International Journal of Innovative Technology and Exploring Engineering (IJITEE) ISSN: 2278-3075, Volume-8, Issue-11S2, September 2019

\begin{tabular}{|c|c|c|c|c|c|c|}
\hline $\begin{array}{l}\text { Canara } \\
\text { Bank }\end{array}$ & $\begin{array}{l}\text { agricultural } \\
\text { lending }\end{array}$ & time (in years) & 5061.13 & $\begin{array}{l}10.67 \\
(\mathbf{0 . 0 0 0}) * *\end{array}$ & $\begin{array}{l}114.02 \\
(\mathbf{0 . 0 0 0}) * *\end{array}$ & $93.4 \%$ \\
\hline $\begin{array}{l}\text { Central Bank of } \\
\text { India }\end{array}$ & $\begin{array}{l}\text { agricultural } \\
\text { lending }\end{array}$ & time (in years) & 3059.02 & $\begin{array}{l}11.18 \\
(\mathbf{0 . 0 0 0}) * *\end{array}$ & $\begin{array}{l}125.03 \\
(\mathbf{0 . 0 0 0 )} * *\end{array}$ & $94 \%$ \\
\hline $\begin{array}{l}\text { Corporation } \\
\text { Bank }\end{array}$ & $\begin{array}{l}\text { agricultural } \\
\text { lending }\end{array}$ & time (in years) & 1388.00 & $\begin{array}{l}6.68 \\
(\mathbf{0 . 0 0 0}) * *\end{array}$ & $\begin{array}{l}44.68 \\
(\mathbf{0 . 0 0 0}) * *\end{array}$ & $84.8 \%$ \\
\hline $\begin{array}{l}\text { Dena } \\
\text { Bank }\end{array}$ & $\begin{array}{l}\text { agricultural } \\
\text { lending }\end{array}$ & time (in years) & 1009.41 & $\begin{array}{l}8.29 \\
(\mathbf{0 . 0 0 0}) * *\end{array}$ & $\begin{array}{l}68.84 \\
(\mathbf{0 . 0 0 0}) * *\end{array}$ & $89.6 \%$ \\
\hline $\begin{array}{l}\text { Indian } \\
\text { Bank }\end{array}$ & $\begin{array}{l}\text { agricultural } \\
\text { lending }\end{array}$ & time (in years) & 1857.50 & $\begin{array}{l}11.97 \\
(\mathbf{0 . 0 0 0}) * *\end{array}$ & $\begin{array}{l}143.40 \\
(\mathbf{0 . 0 0 0}) * *\end{array}$ & $95.3 \%$ \\
\hline $\begin{array}{l}\text { Indian Overseas } \\
\text { Bank }\end{array}$ & $\begin{array}{l}\text { agricultural } \\
\text { lending }\end{array}$ & time (in years) & 2534.50 & $\begin{array}{l}15.23 \\
(\mathbf{0 . 0 0 0}) * *\end{array}$ & $\begin{array}{l}231.98 \\
(\mathbf{0 . 0 0 0 )} * *\end{array}$ & $96.7 \%$ \\
\hline $\begin{array}{l}\text { Oriental Bank of } \\
\text { Commerce }\end{array}$ & $\begin{array}{l}\text { agricultural } \\
\text { lending }\end{array}$ & time (in years) & 2115.08 & $\begin{array}{l}20.53 \\
(\mathbf{0 . 0 0 0}) * *\end{array}$ & $\begin{array}{l}421.60 \\
(\mathbf{0 . 0 0 0}) * *\end{array}$ & $98.1 \%$ \\
\hline $\begin{array}{l}\text { Punjab and Sind } \\
\text { Bank }\end{array}$ & $\begin{array}{l}\text { agricultural } \\
\text { lending }\end{array}$ & time (in years) & 732.58 & $\begin{array}{l}7.49 \\
(\mathbf{0 . 0 0 0})^{* *}\end{array}$ & $\begin{array}{l}56.16 \\
(\mathbf{0 . 0 0 0 )} * *\end{array}$ & $87.5 \%$ \\
\hline $\begin{array}{l}\text { Punjab National } \\
\text { Bank }\end{array}$ & $\begin{array}{l}\text { agricultural } \\
\text { lending }\end{array}$ & time (in years) & 5033.00 & $\begin{array}{l}10.74 \\
(\mathbf{0 . 0 0 0}) * *\end{array}$ & $\begin{array}{l}115.50 \\
(\mathbf{0 . 0 0 0 )} * *\end{array}$ & $93.5 \%$ \\
\hline $\begin{array}{l}\text { Syndicate } \\
\text { Bank }\end{array}$ & $\begin{array}{l}\text { agricultural } \\
\text { lending }\end{array}$ & time (in years) & 2167.18 & $\begin{array}{l}22.05 \\
(\mathbf{0 . 0 0 0}) * *\end{array}$ & $\begin{array}{l}486.19 \\
(\mathbf{0 . 0 0 0}) * *\end{array}$ & $98.4 \%$ \\
\hline UCO Bank & $\begin{array}{l}\text { agricultural } \\
\text { lending }\end{array}$ & time (in years) & 1388.53 & $\begin{array}{l}5.80 \\
(\mathbf{0 . 0 0 0}) * *\end{array}$ & $\begin{array}{l}33.64 \\
(\mathbf{0 . 0 0 0 ) * *}\end{array}$ & $80.8 \%$ \\
\hline $\begin{array}{l}\text { Union Bank of } \\
\text { India }\end{array}$ & $\begin{array}{l}\text { agricultural } \\
\text { lending }\end{array}$ & time (in years) & 2565.41 & $\begin{array}{l}6.51 \\
(\mathbf{0 . 0 0 0})^{* *}\end{array}$ & $\begin{array}{l}42.46 \\
(\mathbf{0 . 0 0 0}) * *\end{array}$ & $84.1 \%$ \\
\hline $\begin{array}{l}\text { United Bank of } \\
\text { India }\end{array}$ & $\begin{array}{l}\text { agricultural } \\
\text { lending }\end{array}$ & time (in years) & 933.14 & $\begin{array}{l}7.69 \\
(\mathbf{0 . 0 0 0}) * *\end{array}$ & $\begin{array}{l}59.22 \\
(\mathbf{0 . 0 0 0 )} * *\end{array}$ & $88.1 \%$ \\
\hline $\begin{array}{l}\text { Vijaya } \\
\text { Bank }\end{array}$ & $\begin{array}{l}\text { agricultural } \\
\text { lending }\end{array}$ & time (in years) & 956.16 & $\begin{array}{l}7.68 \\
(\mathbf{0 . 0 0 0})^{* *}\end{array}$ & $\begin{array}{l}59.01 \\
(\mathbf{0 . 0 0 0 )} * *\end{array}$ & $88.1 \%$ \\
\hline
\end{tabular}

